\title{
Improving sample representativeness in environmental studies: a major component for the uncertainty budget
}

\author{
Elvis J. De França · Elisabete A. De Nadai Fernandes • \\ Márcio A. Bacchi - Peter Bode · Rob T. M. van Soldt
}

Received: 17 July 2009/Published online: 28 August 2009

(c) Akadémiai Kiadó, Budapest, Hungary 2009

\begin{abstract}
For environmental quality assessment, INAA has been applied for determining chemical elements in small $(200 \mathrm{mg})$ and large (200 g) samples of leaves from 200 trees. By applying the Ingamells' constant, the expected percent standard deviation was estimated in $0.9-$ $2.2 \%$ for $200 \mathrm{mg}$ samples. Otherwise, for composite samples $(200 \mathrm{~g})$, expected standard deviation varied from 0.5 to $10 \%$ in spite of analytical uncertainties ranging from 2 to $30 \%$. Results thereby suggested the expression of the degree of representativeness as a source of uncertainty, contributing for increasing of the reliability of environmental studies mainly in the case of composite samples.
\end{abstract}

Keywords LS-INAA · Sampling error · Ingamells' constant · Dense Ombrophilous Forest

E. J. De França $(\bowtie)$ - E. A. De Nadai Fernandes · M. A. Bacchi Centro de Energia Nuclear na Agricultura, Universidade de São Paulo, P.O. Box 96, Piracicaba, SP 13400-970, Brazil

e-mail: ejfranca@usp.br

E. A. De Nadai Fernandes

e-mail: lis@cena.usp.br

M. A. Bacchi

e-mail: mabacchi@cena.usp.br

P. Bode $\cdot$ R. T. M. van Soldt

Reactor Institute of Delft, Section of Radiation and Isotopes for Health, Department of Radiation, Radionuclides and Reactors, Faculty of Applied Sciences, Delft University of Technology, Mekelweg 15, 2629 JB Delft, The Netherlands

P. Bode

e-mail: P.Bode@IRI.TUDelft.NL

R. T. M. van Soldt

e-mail: R.Soldt@IRI.TUDelft.NL

\section{Introduction}

The size of the test portion in chemical analysis is usually quite small, varying from sub-milligram amounts (e.g. in laser-ablation ICP) to a few grams (e.g. in XRF). As such, very high demands are set to assure representativeness of these test portions for the sample collected and/or the population studied, in which composite sampling is usually employed. Inhomogeneity is one of the basic causes of the sampling error. Macroscopic inhomogeneities can be simply observed, e.g. with samples composed of clearly different materials, or of different particle sizes. Microscopic inhomogeneities also exist, and are much more difficult to account for. This is e.g. the case with trace substances, like trace elements with mass fractions in the $\mathrm{mg} \mathrm{kg}^{-1}$ to $\mu \mathrm{g} \mathrm{kg}^{-1}$ ranges. In addition, inhomogeneities may occur due to physical phenomena with the material collected, like segregation, grouping and sometimes microbiological activities. The sampling error is seldom properly assessed, simply because it would imply costly homogenization studies involving at least 10 replicates of a test portion [1-3]. Consequently, the percent standard deviation of mass fraction of chemical elements is often underestimated in many environmental studies.

As a complete alternative, the direct analysis of large samples has been proposed, taking advantage of the analytical characteristics of INAA [4-6]. Large sample (LS) INAA also allows the direct assessment of the sampling error since the large sample result can be compared with the result of conventional analysis on a small test portion of the same population studied [7]. The large sample analysis technique even allows for determination and identification of local inhomogeneities [8, 9]. However, for almost all environmental studies, the sampling of a huge amount of material can be unreasonable mainly in natural protected 
areas, seldom resulting in a composite sampling design. As such, the minimum sample mass to attain a predefined percent standard deviation cannot be easily verified.

For that reason, the degree of representativeness may be considered as a source of uncertainty. The basic problem, however, is the estimation of the minimum sample mass at which the coefficient of variation of a chemical element mass fraction is-with a certain degree of confidencebelow a predefined level. This has been elaborated through the development of empirical relations, the most well known are the sampling constants by Ingamells [1, 2] and by Wallace and Kratochvil [3]. The sampling constant, $K_{\mathrm{s}}$, is firstly estimated for each element on basis of the standard deviation of analysis of replicates of a given sample mass. Next, the square root of this constant is numerically equal to the expected percent standard deviation for the obtained results in sub-samples of $1 \mathrm{~g}$ for a method free from analytical errors [1]. This sampling constant can be also used to estimate the minimum sample mass for attaining a given acceptable (minimum) variation, e.g. $1 \%$ due to the subsampling.

In this work, the degree of representativeness of individual and composite samples of the leaf compartment from an Atlantic Forest ecosystem was studied applying the Ingamells' sampling constant $[1,2]$. The test portions were analyzed by instrumental neutron activation analysis (INAA) aiming at the evaluation of the expected percent standard deviation as a source of uncertainty for leaf analysis of one tree (ten test portions), one species (ten trees) and composite samples. In the last case, samples of approximately $200 \mathrm{~g}$ were analyzed by LS INAA to facilitate the evaluation of the degree of representativeness for species population.

\section{Experimental}

Sampling for one tree/one species

Leaves (500 g) of a Marlierea tomentosa tree were used to assess the representativeness of $200 \mathrm{mg}$ samples, which is the mass routinely used for normal INAA. Details of experimental design are described elsewhere [10]. The most abundant tree species from a long-term plot of $0.1 \mathrm{~km}^{2}$ in the Parque Estadual Carlos Botelho (PECB), São Paulo State, Brail, are presented in Table 1. This conservation unit has about $380 \mathrm{~km}^{2}$ of Atlantic Forest. Summarily, for each species, leaves $(500 \mathrm{~g})$ of ten trees were sampled from middle- and lower-crown in March 2003, January 2004 and July 2004. Samples were washed with tap water, oven-dried at $60{ }^{\circ} \mathrm{C}$ until constant weight and milled in titanium mill to reduce particle size.

\section{Sampling for composite samples}

In earlier work [11] it has been demonstrated that, at the 95\% confidence level, the seasons have no influence on the element mass fractions in the compartments studied in
Table 1 Most abundant tree species for leaf sampling in the Parque Estadual Carlos Botelho (PECB)

$N$ total number of trees in the long-term plot, $n$ number of sampled trees

\begin{tabular}{llrr}
\hline Family & Species & $N$ & $n$ \\
\hline Cyatheaceae & Alsophila sternbergii (Pohl) Conant. & 342 & 10 \\
Rubiaceae & Bathysa australis K. Schum. & 210 & 10 \\
Myrtaceae & Calycorectes australis D. Legrand & 108 & 7 \\
Sapotaceae & Chrysophyllum innornatum Mart. & 83 & 9 \\
Sapotaceae & Chrysophyllum viride Mart. \& Eichler ex Miq. & 104 & 10 \\
Myrtaceae & Eugenia cuprea (O. Berg) Nied. & 143 & 8 \\
Arecaceae & Euterpe edulis Mart. & 1761 & 19 \\
Myrtaceae & Eugenia mosenii (Kausel) Sobral & 117 & 9 \\
Myrtaceae & Eugenia melanogyna (D. Legrand) Sobral & 124 & 10 \\
Lauraceae & Endlicheria paniculata (Spreng.) J. F. Macbr. & 103 & 11 \\
Myrtaceae & Gomidesia flagellaris D. Legrand & 122 & 10 \\
Clusiaceae & Garcinia gardneriana (Planch. \& Triana) D. Zappi & 259 & 10 \\
Nyctaginaceae & Guapira opposita (Vell.) Reitz & 333 & 10 \\
Phyllantaceae & Hyeronima alchorneoides Allemão & 126 & 10 \\
Myrtaceae & Marlierea suaveolens Cambess. & 126 & 10 \\
Myrtaceae & Marlierea tomentosa Cambess. & 104 & 9 \\
Myrtaceae & Neomitranthes glomerata (D. Legrand) D. Legrand & 99 & 10 \\
Rubiaceae & Rudgea jasminoides (Cham.) Müll. Arg. & 137 & 10 \\
Olacaceae & Tetrastylidium grandifolium (Baill.) Sleumer & 216 & 10 \\
Myristicaceae & Virola bicuhyba (Schott ex Spreng.) Warb. & 156 & 9 \\
\hline & & &
\end{tabular}


the PECB conservation unit. As such, sampling of the leaf material for the large sample analysis took place in November 2004. Leaves from 10 trees of each species were combined into composite samples for analysis by LSINAA. All samples were dried at room temperature and humidity $\left(24{ }^{\circ} \mathrm{C} ; 60 \%\right)$. After packing into plastic bags, samples were gamma-ray-sterilized (dose: $30 \mathrm{kGray)} \mathrm{by}$ Companhia Brasileira de Esterilização, Jarinú, Brazil, to avoid microbiological degradation and proliferation. The Instituto Brasileiro do Meio Ambiente e dos Recursos Naturais Renováveis (IBAMA), Ministério do Meio Ambiente, Brazil, has authorized the transfer of the samples to The Netherlands for chemical analysis by LS INAA.

Normal instrumental neutron activation analysis

INAA performed at the Radioisotopes Laboratory (LRi) is based on the $k_{0}$ standardization [12] and utilizes the Quantu software [13] for determining chemical elements in diverse kind of material. The analysis steps are summarized below:

- Sample weighting in polyethylene vials specific for neutron irradiation. Test portions of approximately $200 \mathrm{mg}$. Independent portions of $1 \mathrm{~g}$ were separated for moisture determination. Typical moisture content was $5 \%$.

- Irradiation of the small samples and neutron flux monitors for $8 \mathrm{~h}$ in the nuclear research reactor IEAR1, Instituto de Pesquisas Energéticas e Nucleares (IPEN). For neutron flux monitoring, Ni-Cr alloy of known mass fractions of monitor chemical elements was employed [14]. Test portions of $10 \mathrm{mg}$ were sandwiched between the sample vials. Typical thermal neutron flux was $10^{13} \mathrm{~cm}^{-2} \mathrm{~s}^{-1}$.

- Measurement of the induced radioactivity was carried out at LRi with Ge detectors (rel. eff. 45 and 50\%) after 4, 6, 10 and 20 days decay with respective counting times of 1,2 and $10 \mathrm{~h}$. The induced radioactivity of the neutron flux monitors was measured for 5 min after 10 and 15 days decay time.

- Convolution of the gamma-ray spectra and calculation of chemical element mass fractions. The uncertainty of measurement included contributions of weighting, neutron flux variation, counting statistics, gamma-ray self-attenuation correction and $k_{0}$ standardization [13].

Large sample instrumental neutron activation analysis

At the Reactor Institute Delft (RID) of the Delft University of Technology, the dried material was transferred into polyethylene bottles for irradiation in the LS INAA facilities. Details of this procedure can be found elsewhere
$[4,5]$. The average mass of the leaf samples was $200 \mathrm{~g}$, i.e. about 1,000 times higher than the usual test portion (200 mg) in normal INAA. Separate test portions of $50 \mathrm{~g}$ were used to determine the moisture content through freeze-drying until constant weight $(48 \mathrm{~h})$. Typically, the moisture content was $10 \%$. The LS-INAA procedure consists of the following steps:

- Measurement of the natural radioactivity of each large sample (1 h).

- Measurement of the transmission, through each sample, of the gamma-rays emitted by an external ${ }^{152} \mathrm{Eu}+{ }^{154} \mathrm{Eu}$ source $(5 \mathrm{~min})$.

- Calculation of the effective gamma-ray mass attenuation coefficients of each large sample [5].

- Irradiation of the samples and neutron flux monitors in the HOR research nuclear reactor (40 h). Neutron flux monitors were made from $99.99 \%$ high pure $\mathrm{Zn}$ foil to be inserted in the carbon-carbon composite flux-monitor holder of the LS-INAA irradiation container. Typical thermal neutron flux was $3 \times 10^{8} \mathrm{~m}^{-2} \mathrm{~s}^{-1}$.

- Measurement of the induced radioactivity in the sample and flux monitors. The LS-INAA counting facility consists of a gamma-ray spectrometer with horizontal Ge detector (rel. eff. 96\%). Samples are located at $20 \mathrm{~cm}$ distance from the detector end cap and rotated during counting. Measurements of the induced radioactivity in the large sample took place after 0,7 and 20 days decay with respective counting times of 1,2 and $10 \mathrm{~h}$. The induced radioactivity of neutron flux monitors was measured by 15 min using a gamma-ray spectrometer with a well-type Ge detector.

- Calculation of the neutron diffusion length and neutron diffusion coefficient [5].

- Calculation of the correction factors for gamma-ray and neutron self-attenuation. In addition, an empirical correction was applied to account for the neutron attenuation in the void fraction in the bottles.

- Analysis of the gamma-ray spectrum of the induced radioactivity; application of all correction factors and interpretation of the peak areas towards element mass fractions using the calibration constants from the $k_{0}$ method [15].

Ingamells' sampling constant

The sampling constant $K_{\mathrm{s}}$ is estimated on basis of the reproducibility standard deviation of analyzed subsamples of a given mass $[1,2]$. If the analytical uncertainty is small (less than $1 / 3$ of the assumed subsampling error) and $x_{1}$, $x_{2}, \ldots, x_{i}, \ldots, x_{m}$ are the results of $M$ measurements in the subsamples of weight $w(\mathrm{~g}), K_{\mathrm{s}}$ is given by Ingamells $[1,2]$ : 
$\hat{K}_{\mathrm{s}}=\hat{R}^{2} w=\frac{10^{4} w \sum_{i=1}^{M}\left(x_{i}-\bar{x}\right)^{2}}{(M-1) \bar{x}^{2}}$

in which $\bar{x}$ is the mean element concentration of $M$ determinations and $\hat{R}$, the expected percent standard deviation (\%). The percent standard deviation for the same element of sample in a further subsample of mass $w_{\mathrm{F}}$ is estimated by $[1,2]$

$\hat{R}_{\mathrm{F}}=\sqrt{\frac{\hat{K}_{\mathrm{s}}}{w_{\mathrm{F}}}}$

Calculating $\hat{R}_{\mathrm{F}}$ allows combining this estimate of "uncertainty of sampling" with the uncertainty of measurement. This is permitted for $K_{\mathrm{s}}$ derived from a sufficiently large number of previous determinations, in which data are normally distributed (referring to subsample $w_{\mathrm{F}}$ ). Generally, this is already possible if $K_{\mathrm{s}}$ is based on the ten or more measurements, except in the case of fractioning and heterogeneity due to the presence of diverse materials of grossly different composition [1,2].

The sampling constants were estimated for assessing the representativeness of ten small individual leaf subsamples analyzed by normal INAA. For the evaluation of the degree of representativeness of the composite samples analyzed by LS INAA, results from 200 trees collected in three periods were used to estimate the expected percent standard deviation and compared to the analytical uncertainties aimed at assuring a minimum SE.

\section{Results and discussion}

For INAA, the contribution of contamination during the particle size reduction was not taken into account since titanium grinding instruments have been used, and a possible titanium contamination would not interfere on the determinations of chemical elements in biological material. The quality of analytical procedure was evaluated by analysis of the biological certified reference materials IAEA 336 Lichen, IAEA V-10 Hay Powder and INCTTL-1 Tea Leaves, produced by International Atomic Energy Agency and Institute of Nuclear Chemistry and Technology, respectively [11].

\section{One tree representativeness}

Table 2 shows the estimated values of $K_{s}$ for guaranteeing representativeness of one leaf sample analyzed by normal INAA. The mass needed to assure a sampling error of $1 \%$ for Co was estimated at $170 \mathrm{mg}$, while the averaged mass was $195 \mathrm{mg}$. There was considerable contribution of sampling error for the other elements observed in the samples, considering that the uncertainty of measurement is smaller than the sampling error. If compared to earlier published values for $K_{\mathrm{s}}^{2}$, a discrepancy is observed for Fe and $\mathrm{K}$. This might be attributed to the relatively high concentration of these elements since the sample matrix was of geological origin, in which mass fractions can be much higher than in leaves. Moreover, particularly for $\mathrm{Fe}$, the mass fractions can be affected by leaf surface contamination with soil particles [16]. The $K_{\mathrm{s}}^{0.5}$ values obtained for $\mathrm{Na}$ and $\mathrm{Rb}$ were considered in very good agreement with those from the literature. It has been demonstrated by the expected standard deviation $\left(\hat{R}_{\mathrm{F}}\right)$ that the degree of representativeness reached contributions of up to $2 \%$ for Co. It would be expected that the $\hat{R}_{\mathrm{F}}$ values for analyzing of $200 \mathrm{mg}$ test portions from Table 2 should be combined to combined standard uncertainty of measurement to reflect a realistic indication of the range of variation of the results, obtained by normal INAA.

\section{One species representativeness}

As the main problem in biomonitoring studies, the analysis of only one tree/species could not be related to the uptake of all chemical elements in the ecosystem to be evaluated in terms of environmental quality [17]. For that reason, it is common to analyze so many species/trees is possible. However, the results of chemical element mass fractions obtained by normal INAA given in Table 3 are very undesirable since local variances have been determined as very high throughout the analysis of ten trees belonging to the same species. The coefficient of variation ranged from 12 to $137 \%$ depending on the chemical element and the treespecies. As it can be expected, the $K_{\mathrm{s}}$ values (Table 4), that is, the minimum sample mass to be analyzed for assuring sampling error equal to $1 \%$, for the analysis of ten trees of one species were much higher (minimum: $43 \mathrm{~g}$ for determining Fe in Eugenia cuprea population; maximum: $16.6 \mathrm{~kg}$ for Co determination in Neomitranthes glomerata population) compare to the values obtained for $200 \mathrm{mg}$ samples (Table 2). This may be attributed to the larger size of the group of individual samples per species compared to all trees from the same anterior species. As a consequence, $K_{\mathrm{s}}^{0.5}$ values were quite higher due to diverse sources of error involving in the analysis of composite samples by normal INAA. Reducing particle size might solve this problem, although the mass of the samples would be quite high for normal sample preparation procedures [18].

\section{Composite samples}

The immediate answer for evaluating plant population in terms of chemical composition would be the analysis of a huge amount of material as possible. It was suggested by the Ingamell' constant, in which some grams of material could 
Table 2 Chemical element mass fraction $\left(\mathrm{mg} \mathrm{kg}^{-1}\right)$ in Marlierea tomentosa leaves

\begin{tabular}{|c|c|c|c|c|c|c|c|c|}
\hline Subsample & $\mathrm{Br}$ & $\mathrm{Co}$ & $\mathrm{Cs}$ & $\mathrm{Fe}$ & $\mathrm{K}$ & $\mathrm{Na}$ & $\mathrm{Rb}$ & $\mathrm{Sr}$ \\
\hline 1 & 8.40 & 0.497 & 0.163 & 74.7 & 8663 & 336 & 28.4 & 62.4 \\
\hline 2 & 8.38 & 0.506 & 0.156 & 74.8 & 8385 & 332 & 28.1 & 62.9 \\
\hline 3 & 8.66 & 0.505 & 0.166 & 73.9 & 8535 & 343 & 28.4 & 63.7 \\
\hline 4 & 8.52 & 0.495 & 0.161 & 73.0 & 8513 & 336 & 28.1 & 61.0 \\
\hline 5 & 8.57 & 0.502 & 0.161 & 74.9 & 8673 & 338 & 28.4 & 59.9 \\
\hline 6 & 8.57 & 0.505 & 0.167 & 74.2 & 8737 & 342 & 29.5 & 64.0 \\
\hline 7 & 8.42 & 0.496 & 0.159 & 76.3 & 8545 & 340 & 28.7 & 62.1 \\
\hline 8 & 8.69 & 0.507 & 0.163 & 74.0 & 8876 & 347 & 28.7 & 62.7 \\
\hline 9 & 8.48 & 0.500 & 0.163 & 73.7 & 8588 & 341 & 28.5 & 62.8 \\
\hline 10 & 8.46 & 0.504 & 0.162 & 78.7 & 8588 & 335 & 28.2 & 61.8 \\
\hline Mean & 8.52 & 0.502 & 0.162 & 74.8 & 8610 & 339 & 28.5 & 62.3 \\
\hline$K_{\mathrm{s}}$ & 0.31 & 0.17 & 0.70 & 0.92 & 0.48 & 0.31 & 0.40 & 0.73 \\
\hline$K_{\mathrm{s}}^{0.5}($ this work) & 0.56 & 0.42 & 0.84 & 0.96 & 0.69 & 0.56 & 0.64 & 0.85 \\
\hline$K_{\mathrm{s}}^{0.5}$ (Ingamells \& Switzer) [2] & - & - & - & 0.07 & 0.3 & 1 & 1.7 & - \\
\hline$\hat{R}_{\mathrm{F}}(200 \mathrm{mg})$ & 1.25 & 0.93 & 1.88 & 2.15 & 1.55 & 1.25 & 1.42 & 1.91 \\
\hline
\end{tabular}

$K_{\mathrm{s}}^{0.5}$ is the expected standard deviation $\left(1 \mathrm{~g}\right.$ test portions). $\hat{R}_{\mathrm{F}}$ is the expected standard deviation for the analysis of $200 \mathrm{mg}$ test portions

Table 3 Mass fractions of chemical elements $\left(\mathrm{mg} \mathrm{kg}^{-1}\right)$ and the respective local variances in percentage (CV\%) determined by conventional INAA

\begin{tabular}{|c|c|c|c|c|c|c|c|c|c|c|c|c|c|c|c|c|}
\hline \multirow{2}{*}{$\begin{array}{l}\text { INAA } \\
\mathrm{Sp}\end{array}$} & \multicolumn{2}{|l|}{$\mathrm{Br}$} & \multicolumn{2}{|l|}{$\mathrm{Ca}^{\mathrm{a}}$} & \multicolumn{2}{|l|}{ Co } & \multicolumn{2}{|l|}{$\mathrm{Fe}$} & \multicolumn{2}{|l|}{$\mathrm{K}^{\mathrm{a}}$} & \multicolumn{2}{|l|}{$\mathrm{Na}^{\mathrm{a}}$} & \multicolumn{2}{|l|}{$\mathrm{Rb}$} & \multicolumn{2}{|l|}{$\mathrm{Sc}$} \\
\hline & Mea & $\mathrm{CV} \%$ & Mean & CV\% & Mean & $\mathrm{CV} \%$ & Mean & $\mathrm{CV} \%$ & Mean & CV\% & Mean & CV\% & Mean & $\mathrm{CV} \%$ & Mean & $\mathrm{CV} \%$ \\
\hline Aste & 24.8 & 31 & 5.53 & 28 & 0.32 & 38 & 279 & 27 & 6.07 & 29 & 3.22 & 54 & 32.1 & 29 & 0.445 & 63 \\
\hline Baus & 6.40 & 35 & 6.74 & 31 & 1.27 & 116 & 159 & 24 & 22.5 & 14 & 1.93 & 16 & 38.6 & 40 & 0.040 & 17 \\
\hline Caus & 3.96 & 137 & 12.2 & 47 & 0.14 & 47 & 67 & 19 & 18.1 & 23 & 1.07 & 47 & 55.8 & 27 & 0.012 & 29 \\
\hline Cvir & 12.7 & 23 & 7.67 & 14 & 0.10 & 53 & 78 & 34 & 13.6 & 30 & 0.26 & 36 & 37.2 & 30 & 0.014 & 64 \\
\hline Ecup & 17.8 & 23 & 10.5 & 16 & 0.11 & 30 & 126 & 26 & 9.55 & 18 & 0.54 & 44 & 28.6 & 67 & 0.030 & 30 \\
\hline Eedu & 5.61 & 15 & 4.52 & 16 & 0.04 & 60 & 98 & 9 & 11.4 & 17 & 1.56 & 23 & 25.6 & 23 & 0.018 & 22 \\
\hline Emii & 16.8 & 36 & 6.79 & 12 & 0.05 & 46 & 74 & 14 & 17.4 & 42 & 3.13 & 57 & 47.6 & 57 & 0.037 & 70 \\
\hline Emna & 46.1 & 49 & 13.0 & 32 & 0.06 & 47 & 99 & 55 & 14.4 & 31 & 3.68 & 60 & 43.8 & 36 & 0.181 & 76 \\
\hline Gfla & 14.8 & 23 & 7.08 & 22 & 0.13 & 32 & 97 & 21 & 10.5 & 21 & 0.95 & 23 & 28.9 & 26 & 0.020 & 26 \\
\hline Ggar & 5.66 & 39 & 8.25 & 27 & 2.82 & 66 & 59 & 21 & 8.59 & 35 & 0.87 & 29 & 28.8 & 58 & 0.012 & 30 \\
\hline Gopp & 30.8 & 51 & 10.6 & 30 & 0.07 & 45 & 101 & 27 & 25.7 & 15 & 6.58 & 26 & 76.8 & 21 & 0.020 & 48 \\
\hline Halc & 8.07 & 29 & 7.32 & 23 & 0.44 & 55 & 95 & 20 & 11.7 & 19 & 0.78 & 43 & 27.1 & 42 & 0.015 & 27 \\
\hline Msua & 5.80 & 14 & 6.61 & 24 & 0.17 & 30 & 77 & 17 & 6.70 & 27 & 1.62 & 39 & 13.9 & 35 & 0.014 & 26 \\
\hline Mtom & 7.12 & 28 & 5.92 & 29 & 0.18 & 10 & 83 & 33 & 9.36 & 28 & 1.83 & 46 & 33.3 & 62 & 0.016 & 38 \\
\hline Nglo & 3.11 & 44 & 12.7 & 24 & 0.38 & 206 & 61 & 25 & 11.8 & 39 & 0.35 & 27 & 40.3 & 32 & 0.010 & 31 \\
\hline Rjas & 36.7 & 30 & 10.4 & 29 & 0.05 & 26 & 86 & 15 & 13.8 & 21 & 2.01 & 31 & 42.7 & 39 & 0.067 & 47 \\
\hline Tgra & 16.5 & 70 & 3.83 & 34 & 0.03 & 49 & 106 & 43 & 10.3 & 51 & 1.54 & 80 & 36.7 & 35 & 0.021 & 75 \\
\hline Vbic & 3.12 & 39 & 6.17 & 33 & 0.10 & 67 & 84 & 20 & 9.19 & 12 & 0.43 & 52 & 25.8 & 24 & 0.013 & 22 \\
\hline
\end{tabular}

Aste Alsophilla sternbergii, Baus Bathysa australis, Caus Calycorectes australis, Cvir Chrysophyllum viride, Ecup Eugenia cuprea, Eedu Euterpe edulis, Emii Eugenia mosenii, Emna Eugenia melanogyna, Epan Endlicheria paniculata, Gfla Gomidesia flagellaris, Ggar Garcinia gardneriana, Gopp Guapira opposita, Halc Hyeronima alchorneoides, Msua Marlierea suaveolens, Mtom Marlierea tomentosa, Nglo Neomitranthes glomerata, Rjas Rudgea jasminoides, Tgla Tetrastylidium grandifolium, Vbic Virola bicuhyba

${ }^{\mathrm{a}}$ Values in $\mathrm{g} \mathrm{kg}^{-1}$

guarantee SE lower than $1 \%$ (Table 3). By applying LS-INAA to composite samples of about $200 \mathrm{~g}$, chemical element mass fractions of plant species were determined
(Table 5), thereby becoming possible to estimate chemical element composition for plant population. According to the $K_{\mathrm{s}}$ results from Table 4 , it is clear that LS-INAA has 
Table 4 Estimated sampling constants $K_{\mathrm{s}}(\mathrm{g})$ for chemical element determination in leaves considering a sampling error equal to $1 \%$

\begin{tabular}{|c|c|c|c|c|c|c|c|c|c|}
\hline & & $\mathrm{Br}$ & $\mathrm{Ca}$ & Co & $\mathrm{Fe}$ & $\mathrm{K}$ & $\mathrm{Na}$ & $\mathrm{Rb}$ & Sc \\
\hline \multirow[t]{2}{*}{ Aste } & $\mathrm{K}_{\mathrm{s}}$ & $3.39 \mathrm{E} 02$ & 3.71E02 & $6.22 \mathrm{E} 02$ & 4.13E02 & $7.56 \mathrm{E} 01$ & $7.35 \mathrm{E} 02$ & $5.56 \mathrm{E} 02$ & $1.51 \mathrm{E} 03$ \\
\hline & $\mathrm{R}_{\mathrm{LS}-\mathrm{INAA}}$ & $1.50 \mathrm{E} 00$ & $1.57 \mathrm{E} 00$ & 2.04E00 & $1.66 \mathrm{E} 00$ & $7.10 \mathrm{E}-01$ & $2.21 \mathrm{E} 00$ & $1.92 \mathrm{E} 00$ & $3.17 \mathrm{E} 00$ \\
\hline \multirow[t]{2}{*}{ Baus } & $\mathrm{K}_{\mathrm{s}}$ & $6.93 \mathrm{E} 02$ & $1.14 \mathrm{E} 02$ & $1.26 \mathrm{E} 03$ & $6.54 \mathrm{E} 02$ & 2.83E02 & $2.64 \mathrm{E} 02$ & $4.40 \mathrm{E} 02$ & $1.05 \mathrm{E} 03$ \\
\hline & $\mathrm{R}_{\mathrm{LS}-\mathrm{INAA}}$ & $2.15 \mathrm{E} 00$ & $8.71 \mathrm{E}-01$ & $2.90 \mathrm{E} 00$ & $2.09 \mathrm{E} 00$ & $1.37 \mathrm{E} 00$ & $1.33 \mathrm{E} 00$ & $1.71 \mathrm{E} 00$ & 2.64E00 \\
\hline \multirow[t]{2}{*}{ Caus } & $\mathrm{K}_{\mathrm{s}}$ & $1.56 \mathrm{E} 03$ & 3.94E02 & $3.77 \mathrm{E} 02$ & $2.44 \mathrm{E} 02$ & $1.03 \mathrm{E} 02$ & $4.86 \mathrm{E} 02$ & $1.32 \mathrm{E} 02$ & $6.60 \mathrm{E} 02$ \\
\hline & $\mathrm{R}_{\mathrm{LS}-\mathrm{INAA}}$ & $3.22 \mathrm{E} 00$ & $1.62 \mathrm{E} 00$ & $1.59 \mathrm{E} 00$ & $1.28 \mathrm{E} 00$ & $8.29 \mathrm{E}-01$ & $1.80 \mathrm{E} 00$ & $9.37 \mathrm{E}-01$ & $2.10 \mathrm{E} 00$ \\
\hline \multirow[t]{2}{*}{ Cvir } & $\mathrm{K}_{\mathrm{s}}$ & $2.36 \mathrm{E} 02$ & $1.23 \mathrm{E} 02$ & $6.73 \mathrm{E} 02$ & $1.73 \mathrm{E} 03$ & $1.37 \mathrm{E} 02$ & 2.79E02 & $2.08 \mathrm{E} 02$ & $3.41 \mathrm{E} 02$ \\
\hline & $\mathrm{R}_{\mathrm{LS}-\mathrm{INAA}}$ & $1.25 \mathrm{E} 00$ & $9.05 \mathrm{E}-01$ & $2.12 \mathrm{E} 00$ & $3.40 \mathrm{E} 00$ & $9.57 \mathrm{E}-01$ & $1.36 \mathrm{E} 00$ & $1.18 \mathrm{E} 00$ & $1.51 \mathrm{E} 00$ \\
\hline \multirow[t]{2}{*}{ Ecup } & $\mathrm{K}_{\mathrm{s}}$ & $3.33 \mathrm{E} 02$ & 8.01E01 & $6.80 \mathrm{E} 02$ & 4.27E01 & 2.32E02 & $1.22 \mathrm{E} 03$ & 4.42E02 & $1.23 \mathrm{E} 02$ \\
\hline & $\mathrm{R}_{\mathrm{LS}-\mathrm{INAA}}$ & $1.49 \mathrm{E} 00$ & $7.31 \mathrm{E}-01$ & 2.13E00 & $5.33 \mathrm{E}-01$ & $1.24 \mathrm{E} 00$ & $2.85 \mathrm{E} 00$ & $1.72 \mathrm{E} 00$ & $9.07 \mathrm{E}-01$ \\
\hline \multirow[t]{2}{*}{ Eedu } & $\mathrm{K}_{\mathrm{s}}$ & $1.99 \mathrm{E} 02$ & 2.53E02 & $1.16 \mathrm{E} 04$ & $9.16 \mathrm{E} 02$ & $1.73 \mathrm{E} 02$ & 8.57E02 & $1.52 \mathrm{E} 02$ & $1.27 \mathrm{E} 03$ \\
\hline & $\mathrm{R}_{\mathrm{LS}-\mathrm{INAA}}$ & $1.15 \mathrm{E} 00$ & $1.30 \mathrm{E} 00$ & $8.78 \mathrm{E} 00$ & 2.47E00 & $1.07 \mathrm{E} 00$ & 2.39E00 & $1.01 \mathrm{E} 00$ & 2.91E00 \\
\hline \multirow[t]{2}{*}{ Emii } & $\mathrm{K}_{\mathrm{s}}$ & $4.66 \mathrm{E} 02$ & $6.34 \mathrm{E} 01$ & $1.31 \mathrm{E} 03$ & $5.62 \mathrm{E} 01$ & $2.15 \mathrm{E} 02$ & $4.85 \mathrm{E} 02$ & $2.79 \mathrm{E} 02$ & $9.72 \mathrm{E} 02$ \\
\hline & $\mathrm{R}_{\text {LS-INAA }}$ & $1.76 \mathrm{E} 00$ & $6.50 \mathrm{E}-01$ & $2.96 \mathrm{E} 00$ & $6.12 \mathrm{E}-01$ & $1.20 \mathrm{E} 00$ & $1.80 \mathrm{E} 00$ & $1.36 \mathrm{E} 00$ & $2.55 \mathrm{E} 00$ \\
\hline \multirow[t]{2}{*}{ Emna } & $\mathrm{K}_{\mathrm{s}}$ & $3.83 \mathrm{E} 02$ & 1.08E02 & $3.80 \mathrm{E} 02$ & $2.24 \mathrm{E} 02$ & $1.30 \mathrm{E} 02$ & 8.49E02 & $2.19 \mathrm{E} 02$ & $9.82 \mathrm{E} 02$ \\
\hline & $\mathrm{R}_{\text {LS-INAA }}$ & $1.60 \mathrm{E} 00$ & $8.49 \mathrm{E}-01$ & $1.59 \mathrm{E} 00$ & $1.22 \mathrm{E} 00$ & $9.31 \mathrm{E}-01$ & $2.38 \mathrm{E} 00$ & $1.21 \mathrm{E} 00$ & $2.56 \mathrm{E} 00$ \\
\hline \multirow[t]{2}{*}{ Epan } & $\mathrm{K}_{\mathrm{s}}$ & $9.96 \mathrm{E} 01$ & $3.34 \mathrm{E} 02$ & $8.02 \mathrm{E} 02$ & $1.90 \mathrm{E} 02$ & $2.03 \mathrm{E} 02$ & $5.30 \mathrm{E} 02$ & $3.14 \mathrm{E} 02$ & 4.10E02 \\
\hline & $\mathrm{R}_{\text {LS-INAA }}$ & $8.15 \mathrm{E}-01$ & 1.49E00 & $2.31 \mathrm{E} 00$ & $1.12 \mathrm{E} 00$ & $1.16 \mathrm{E} 00$ & $1.88 \mathrm{E} 00$ & $1.45 \mathrm{E} 00$ & $1.65 \mathrm{E} 00$ \\
\hline \multirow[t]{2}{*}{ Gfla } & $\mathrm{K}_{\mathrm{s}}$ & $1.71 \mathrm{E} 02$ & $9.20 \mathrm{E} 01$ & $2.51 \mathrm{E} 02$ & 7.87E01 & $9.59 \mathrm{E} 01$ & 4.73E02 & $1.24 \mathrm{E} 02$ & 1.31E02 \\
\hline & $\mathrm{R}_{\text {LS-INAA }}$ & $1.07 \mathrm{E} 00$ & $7.83 \mathrm{E}-01$ & $1.29 \mathrm{E} 00$ & $7.24 \mathrm{E}-01$ & $7.99 \mathrm{E}-01$ & $1.78 \mathrm{E} 00$ & $9.09 \mathrm{E}-01$ & $9.34 \mathrm{E}-01$ \\
\hline \multirow[t]{2}{*}{ Ggar } & $\mathrm{K}_{\mathrm{s}}$ & $1.79 \mathrm{E} 02$ & $1.21 \mathrm{E} 02$ & $1.19 \mathrm{E} 03$ & $1.98 \mathrm{E} 02$ & $1.12 \mathrm{E} 02$ & $1.98 \mathrm{E} 02$ & $3.51 \mathrm{E} 02$ & $1.82 \mathrm{E} 02$ \\
\hline & $\mathrm{R}_{\mathrm{LS}-\mathrm{INAA}}$ & $1.09 \mathrm{E} 00$ & $8.98 \mathrm{E}-01$ & $2.82 \mathrm{E} 00$ & $1.15 \mathrm{E} 00$ & $8.63 \mathrm{E}-01$ & $1.15 \mathrm{E} 00$ & $1.53 \mathrm{E} 00$ & $1.10 \mathrm{E} 00$ \\
\hline \multirow[t]{2}{*}{ Gopp } & $\mathrm{K}_{\mathrm{s}}$ & $2.30 \mathrm{E} 02$ & 1.93E02 & $4.60 \mathrm{E} 02$ & $1.02 \mathrm{E} 02$ & $1.21 \mathrm{E} 02$ & 7.75E01 & $1.20 \mathrm{E} 02$ & $3.78 \mathrm{E} 02$ \\
\hline & $\mathrm{R}_{\text {LS-INAA }}$ & $1.24 \mathrm{E} 00$ & $1.13 \mathrm{E} 00$ & $1.75 \mathrm{E} 00$ & $8.26 \mathrm{E}-01$ & $8.97 \mathrm{E}-01$ & $7.19 \mathrm{E}-01$ & $8.94 \mathrm{E}-01$ & $1.59 \mathrm{E} 00$ \\
\hline \multirow[t]{2}{*}{ Halc } & $\mathrm{K}_{\mathrm{s}}$ & $1.49 \mathrm{E} 02$ & $2.14 \mathrm{E} 02$ & $7.27 \mathrm{E} 02$ & $1.72 \mathrm{E} 03$ & $1.53 \mathrm{E} 02$ & 2.33E02 & $2.94 \mathrm{E} 02$ & $5.34 \mathrm{E} 02$ \\
\hline & $\mathrm{R}_{\text {LS-INAA }}$ & $9.97 \mathrm{E}-01$ & $1.19 \mathrm{E} 00$ & $2.20 \mathrm{E} 00$ & $3.38 \mathrm{E} 00$ & $1.01 \mathrm{E} 00$ & $1.25 \mathrm{E} 00$ & $1.40 \mathrm{E} 00$ & $1.89 \mathrm{E} 00$ \\
\hline \multirow[t]{2}{*}{ Msua } & $\mathrm{K}_{\mathrm{s}}$ & $1.34 \mathrm{E} 02$ & $1.08 \mathrm{E} 02$ & $1.74 \mathrm{E} 02$ & 7.65E01 & $1.93 \mathrm{E} 02$ & $2.56 \mathrm{E} 02$ & $2.65 \mathrm{E} 02$ & $1.41 \mathrm{E} 02$ \\
\hline & $\mathrm{R}_{\mathrm{LS}-\mathrm{INAA}}$ & $9.44 \mathrm{E}-01$ & $8.48 \mathrm{E}-01$ & $1.08 \mathrm{E} 00$ & $7.14 \mathrm{E}-01$ & $1.13 \mathrm{E} 00$ & $1.31 \mathrm{E} 00$ & $1.33 \mathrm{E} 00$ & $9.71 \mathrm{E}-01$ \\
\hline \multirow[t]{2}{*}{ Mtom } & $\mathrm{K}_{\mathrm{s}}$ & $3.18 \mathrm{E} 02$ & $5.89 \mathrm{E} 02$ & $3.17 \mathrm{E} 03$ & $1.80 \mathrm{E} 02$ & $2.48 \mathrm{E} 02$ & $4.34 \mathrm{E} 02$ & $1.07 \mathrm{E} 03$ & $1.50 \mathrm{E} 03$ \\
\hline & $\mathrm{R}_{\mathrm{LS}-\mathrm{INAA}}$ & $1.46 \mathrm{E} 00$ & $1.98 \mathrm{E} 00$ & $4.60 \mathrm{E} 00$ & $1.10 \mathrm{E} 00$ & $1.29 \mathrm{E} 00$ & $1.70 \mathrm{E} 00$ & 2.67E00 & $3.16 \mathrm{E} 00$ \\
\hline \multirow[t]{2}{*}{ Nglo } & $\mathrm{K}_{\mathrm{s}}$ & 4.43E02 & 7.19E01 & $1.66 \mathrm{E} 04$ & $1.74 \mathrm{E} 03$ & 8.92E01 & $2.21 \mathrm{E} 02$ & $1.49 \mathrm{E} 02$ & $2.57 \mathrm{E} 02$ \\
\hline & $\mathrm{R}_{\text {LS-INAA }}$ & $1.72 \mathrm{E} 00$ & $6.92 \mathrm{E}-01$ & $1.05 \mathrm{E} 01$ & $3.40 \mathrm{E} 00$ & $7.71 \mathrm{E}-01$ & $1.21 \mathrm{E} 00$ & $9.97 \mathrm{E}-01$ & $1.31 \mathrm{E} 00$ \\
\hline \multirow[t]{2}{*}{ Rjas } & $\mathrm{K}_{\mathrm{s}}$ & $8.50 \mathrm{E} 02$ & $5.60 \mathrm{E} 01$ & $1.20 \mathrm{E} 03$ & $2.23 \mathrm{E} 03$ & $2.12 \mathrm{E} 02$ & $2.60 \mathrm{E} 02$ & $3.53 \mathrm{E} 02$ & 8.74E02 \\
\hline & $\mathrm{R}_{\mathrm{LS}-\mathrm{INAA}}$ & $2.38 \mathrm{E} 00$ & $6.11 \mathrm{E}-01$ & $2.83 \mathrm{E} 00$ & $3.86 \mathrm{E} 00$ & $1.19 \mathrm{E} 00$ & $1.32 \mathrm{E} 00$ & $1.53 \mathrm{E} 00$ & $2.41 \mathrm{E} 00$ \\
\hline \multirow[t]{2}{*}{ Tgra } & $\mathrm{K}_{\mathrm{s}}$ & $2.38 \mathrm{E} 02$ & 2.01E02 & $3.90 \mathrm{E} 02$ & $1.26 \mathrm{E} 02$ & $5.95 \mathrm{E} 01$ & $2.82 \mathrm{E} 02$ & $1.94 \mathrm{E} 02$ & $4.45 \mathrm{E} 02$ \\
\hline & $\mathrm{R}_{\text {LS-INAA }}$ & $1.26 \mathrm{E} 00$ & $1.16 \mathrm{E} 00$ & $1.61 \mathrm{E} 00$ & $9.18 \mathrm{E}-01$ & $6.30 \mathrm{E}-01$ & $1.37 \mathrm{E} 00$ & $1.14 \mathrm{E} 00$ & $1.72 \mathrm{E} 00$ \\
\hline \multirow[t]{2}{*}{ Vbic } & $\mathrm{K}_{\mathrm{s}}$ & $5.98 \mathrm{E} 02$ & 2.47E02 & $6.21 \mathrm{E} 02$ & $1.98 \mathrm{E} 02$ & $1.25 \mathrm{E} 02$ & $8.01 \mathrm{E} 02$ & $2.62 \mathrm{E} 02$ & 8.94E02 \\
\hline & $\mathrm{R}_{\text {LS-INAA }}$ & $2.00 \mathrm{E} 00$ & $1.28 \mathrm{E} 00$ & 2.04E00 & $1.15 \mathrm{E} 00$ & $9.13 \mathrm{E}-01$ & $2.31 \mathrm{E} 00$ & $1.32 \mathrm{E} 00$ & 2.44E00 \\
\hline
\end{tabular}

$\mathrm{R}_{\mathrm{LS}-\mathrm{INAA}}$ refer to the expected standard deviation for samples analyzed by LS INAA (200 $\mathrm{g}$ sample size)

Aste Alsophilla sternbergii, Baus Bathysa australis, Caus Calycorectes australis, Cvir Chrysophyllum viride, Ecup Eugenia cuprea, Eedu Euterpe edulis, Emii Eugenia mosenii, Emna Eugenia melanogyna, Epan Endlicheria paniculata, Gfla Gomidesia flagellaris, Ggar Garcinia gardneriana, Gopp Guapira opposita, Halc Hyeronima alchorneoides, Msua Marlierea suaveolens, Mtom Marlierea tomentosa, Nglo Neomitranthes glomerata, Rjas Rudgea jasminoides, Tgla Tetrastylidium grandifolium, Vbic Virola bicuhyba

improved the sample representativeness since, for $70 \%$ of cases, the composite sample mass utilized in LS-INAA were compatible to those estimated for assuring a small sample errors (from 1 to $10 \%$ ) bar the cases of $\mathrm{Co}, \mathrm{Na}$ and $\mathrm{Sc}$ determination in some tree species. The analytical uncertainties obtained by LS-INAA (Table 5) were considerably smaller than the expected percent standard deviations (i.e. reproducibility) from conventional INAA results (Table 4). For example, the concentration of Co estimated for Bathysa australis showed a percent standard deviation of 
Table 5 Mass fractions of chemical elements $\left(\mathrm{mg} \mathrm{kg}^{-1}\right)$ and analytical uncertainties (u\%) determined by LS-INAA

\begin{tabular}{|c|c|c|c|c|c|c|c|c|c|c|c|c|c|c|c|c|}
\hline \multirow{2}{*}{$\begin{array}{l}\text { LS INAA } \\
\mathrm{Sp}\end{array}$} & \multicolumn{2}{|l|}{$\mathrm{Br}$} & \multicolumn{2}{|l|}{$\mathrm{Ca}^{\mathrm{a}}$} & \multicolumn{2}{|l|}{$\mathrm{Co}$} & \multicolumn{2}{|l|}{$\mathrm{Fe}$} & \multicolumn{2}{|l|}{$\mathrm{K}^{\mathrm{a}}$} & \multicolumn{2}{|l|}{$\mathrm{Na}^{\mathrm{a}}$} & \multicolumn{2}{|l|}{$\mathrm{Rb}$} & \multicolumn{2}{|l|}{$\mathrm{Sc}$} \\
\hline & Mean & $\mathrm{u} \%$ & Mean & $\mathrm{u} \%$ & Mean & $\mathrm{u} \%$ & Mean & $\mathrm{u} \%$ & Mean & $\mathrm{u} \%$ & Mean & $\mathrm{u} \%$ & Mean & $\mathrm{u} \%$ & Mean & $\mathrm{u} \%$ \\
\hline Aste & 15.4 & 3 & $<2.70$ & & 0.42 & 30 & 183 & 30 & 6.48 & 3 & 1.39 & 2 & 34.5 & 9 & 0.25 & 10 \\
\hline Baús & 6.83 & 9 & 6.34 & 30 & 0.34 & 20 & 366 & 10 & 12.7 & 2 & 1.03 & 2 & 21.8 & 10 & 0.12 & 7 \\
\hline Caus & 4.93 & 4 & 10.6 & 50 & $<0.80$ & & $<500$ & & 19.9 & 2 & 1.52 & 2 & 52.1 & 6 & 0.04 & 30 \\
\hline Cvir & 15.6 & 2 & 9.86 & 20 & 0.25 & 30 & 169 & 30 & 16.2 & 2 & 0.38 & 2 & 35.9 & 8 & 0.02 & 40 \\
\hline Ecup & 17.9 & 2 & 16.9 & 20 & 0.36 & 30 & 176 & 30 & 7.39 & 2 & 0.62 & 2 & 15.5 & 30 & 0.06 & 13 \\
\hline Eedu & 4.22 & 3 & 4.29 & 20 & 0.32 & 9 & 98.6 & 13 & 4.20 & 2 & 0.12 & 2 & 12.9 & 7 & 0.03 & 12 \\
\hline Emii & 12.7 & 2 & 6.34 & 40 & 0.25 & 9 & 91.5 & 14 & 12.4 & 2 & 3.36 & 2 & 26.1 & 4 & 0.06 & 12 \\
\hline Emna & 56.3 & 2 & 17.6 & 20 & 0.33 & 20 & 134 & 40 & 14.0 & 2 & 2.43 & 2 & 33.1 & 5 & 0.30 & 4 \\
\hline Gfla & 14.6 & 2 & 7.04 & 20 & 0.59 & 13 & $<500$ & & 9.72 & 2 & 1.20 & 2 & 11.3 & 30 & 0.05 & 9 \\
\hline Ggar & 3.87 & 3 & 5.91 & 11 & 2.71 & 3 & $<500$ & & 5.21 & 2 & 0.63 & 2 & 11.3 & 14 & 0.02 & 10 \\
\hline Gopp & 25.1 & 2 & 12.0 & 13 & 0.18 & 40 & 141 & 20 & 28.4 & 2 & 6.83 & 2 & 76.0 & 4 & 0.03 & 30 \\
\hline Halc & 11.0 & 2 & 9.15 & 11 & 0.61 & 10 & 176 & 9 & 14.9 & 2 & 1.09 & 2 & 23.9 & 5 & 0.05 & 7 \\
\hline Msua & 7.82 & 2 & 6.34 & 20 & 0.27 & 11 & 84.5 & 20 & 10.1 & 2 & 1.88 & 2 & 32.4 & 5 & 0.03 & 11 \\
\hline Mtom & 6.34 & 2 & 7.04 & 20 & 0.30 & 14 & 63.4 & 50 & 7.25 & 2 & 1.62 & 2 & 17.6 & 9 & 0.02 & 20 \\
\hline Nglo & 2.07 & 3 & 7.67 & 10 & $<0.80$ & & 56.3 & 20 & 5.28 & 2 & 0.25 & 2 & 16.9 & 7 & 0.02 & 20 \\
\hline Rjas & 37.0 & 2 & 9.15 & 12 & $<0.80$ & & 127 & 20 & 12.9 & 2 & 1.94 & 2 & 33.8 & 7 & 0.08 & 6 \\
\hline Tgra & 25.3 & 2 & 4.93 & 40 & 0.18 & 20 & 162 & 20 & 14.2 & 3 & 3.01 & 2 & 30.3 & 5 & 0.05 & 11 \\
\hline Vbic & 5.14 & 2 & 6.83 & 13 & 0.24 & 12 & 183 & 13 & 10.2 & 2 & 0.75 & 2 & 23.9 & 6 & 0.02 & 30 \\
\hline
\end{tabular}

Aste Alsophilla sternbergii, Baus Bathysa australis, Caus Calycorectes australis, Cvir Chrysophyllum viride, Ecup Eugenia cuprea, Eedu Euterpe edulis, Emii Eugenia mosenii, Emna Eugenia melanogyna, Epan Endlicheria paniculata, Gfla Gomidesia flagellaris, Ggar Garcinia gardneriana, Gopp Guapira opposita, Halc Hyeronima alchorneoides, Msua Marlierea suaveolens, Mtom Marlierea tomentosa, Nglo Neomitranthes glomerata, Rjas Rudgea jasminoides, Tgla Tetrastylidium grandifolium, Vbic Virola bicuhyba

${ }^{\text {a }}$ Values in $\mathrm{g} \mathrm{kg}^{-1}$

$116 \%$ (Table 3), which is quite higher than the uncertainty of $20 \%$ obtained by LS-INAA (Table 5). However, it can be seen from Table 4 that, by the sampling constant calculation, at least $0.5-10 \%$ of expected variation for $200 \mathrm{~g}$ samples analyzed by LS INAA can be expected from sample representativeness variance. Although it might be argued that these values could be overestimated due to the rigorous sampling error of $1 \%$ required in the calculation, being fairly impracticable. Results thereby suggested a possible combination of the combined standard uncertainty of measurement with the expected percent deviation for a more realistic indication of the range of variation of the results obtained by LS INAA.

\section{Conclusions}

The sample representativeness study was carried out in analyzing various dimensions of test portion mass. In the case of small samples of leaf compartment, the analyzed portion was considered satisfactory. There was a significant contribution of the total sampling error estimated by the expected percent standard deviation for the standard uncertainty of measurement estimated for INAA. By increasing the sample dimension from leaves to tree species, LS INAA provided an increasing in sample representativeness due to the reduction of the sampling error by the analysis of large samples (approximately $200 \mathrm{~g}$ ). To improve reliability of these results, it was suggested adding the expected percent standard deviation resulted from sample variance to the analytical uncertainty of measurement in INAA and LS INAA.

Acknowledgement The authors are thankful to the State of São Paulo Research Foundation (Process number 03/01075-2) for financial support. This work was also supported by the Programme $\mathrm{Al} \beta \mathrm{an}$, The European Union Programme of High Level Scholarships for Latin America, scholarship no. E04D041455BR.

\section{References}

1. Ingamells CO (1974) Talanta 21:141

2. Ingamells CO, Switzer P (1973) Talanta 20:547

3. Wallace D, Kratochvil B (1987) Anal Chem 59:226

4. Bode P, Lakmaker O, van Aller P, Blaauw M (1998) Fresenius J Anal Chem 360:10

5. Overwater RMW (1994) Ph.D. Dissertation, TU Delft, Delft University Press, Delft, p 177

6. Lakmaker O, Blaauw M (1997) J Radioanal Nucl Chem 216:69

7. De Nadai Fernandes EA, Bode P (2000) J Radioanal Nucl Chem 244:589 
8. Baas HW, Blaauw M, Bode P, De Goeij JJM (1999) Fresenius J Anal Chem 363:753

9. Baas HW (2004) Ph.D. Dissertation, TU Delft, Delft University Press, Delft, p 160

10. França EJ, De Nadai Fernandes EA, Bacchi MA, Saiki M (2006) Braz Arch Biol Technol 49:101

11. França EJ (2006) Ph.D. Dissertation, USP, ESALQ, Piracicaba, p 380 (in Portuguese)

12. Bacchi MA, De Nadai Fernandes EA, Oliveira H (2000) J Radioanal Nucl Chem 245:217
13. Bacchi MA, De Nadai Fernandes EA (2003) J Radioanal Nucl Chem 257:577

14. França EJ, De Nadai Fernandes EA, Bacchi MA (2003) J Radioanal Nucl Chem 257:113

15. Blaauw M (1997) J Radioanal Nucl Chem 220:233

16. Ferrari AA, França EJ, De Nadai Fernandes EA, Bacchi MA (2006) J Radioanal Nucl Chem 270:69

17. Mertens J, Luyssaert S, Verheyen K (2005) Environ Pollut 138:1

18. Petersen L, Minkkinen P, Esbensen KH (2005) Chemom Intell Lab Syst 77:261 